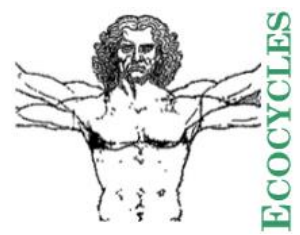

Ecocycles, Vol. 7, No. 2, pp. 23-34 (2021)

DOI: $10.19040 /$ ecocycles.v7i2.199

\title{
The influence of agriculture on the chemical composition of aerosols in the coastal zone of the Southern Baltic Sea (Gdynia)
}

\author{
${ }^{1}$ Martyna Malinowska, ${ }^{2 *}$ Anita U. Lewandowska, ${ }^{3}$ Michalina Bielawska \\ Institute of Oceanography, University of Gdansk \\ Al. Marszałka J. Piłsudskiego 46, 81-378 Gdynia, Poland \\ 1'martynakali@gmail.com \\ 2*anita.lewandowska@ug.edu.pl - corresponding author \\ 33ichalina.bielawska@ug.edu.pl
}

\begin{abstract}
In order to improve soil quality, size, and appearance of plants, various types of fertilizers are used in Poland. They are rich in nitrogen, phosphorus, calcium, and potassium. Plants are fertilized before sowing, during germination, and during crop growth. Such agricultural activity can have a negative effect on the chemical composition of atmospheric aerosols, which can be transported with air masses far away from the agricultural sources regions. The aim of the research was to estimate the influence of agriculture on the chemical composition of aerosols of various sizes $(<0.45$ to $10 \mu \mathrm{m})$ in the atmosphere of the coastal zone of the Baltic Sea. The samples were collected in Gdynia, from 11/05/2016 to 17/08/2016, only outside traffic hours (10:00 a.m. - 3:00 p.m.) and only when air masses were transported from over agricultural areas. Aerosols were collected using Tisch Environmental high-flow impactor. The ions $\left(\mathrm{NO}_{3}{ }^{-}, \mathrm{PO}_{4}{ }^{3-}, \mathrm{K}^{+}, \mathrm{Ca}^{2+}\right)$ were determined by Metrohm ion chromatography (881 Compact IC pro). The obtained results allowed us to conclude that the highest mean concentrations of $\mathrm{NO}_{3}{ }^{-}, \mathrm{K}^{+}, \mathrm{Ca}^{2+}$ occurred in aerosols below $0.45 \mu \mathrm{m}$ in diameter $\left(0.26,0.04\right.$ and $5.85 \mu \mathrm{g} \cdot \mathrm{m}^{-3}$, respectively). Phosphates showed the highest average concentration $\left(0.191 \mu \mathrm{g} \cdot \mathrm{m}^{-3}\right)$ in aerosols with a diameter from 1.5 to $3.0 \mu \mathrm{m}$. The concentration of calcium and nitrates was the highest in the days when advection from Western Kashubia was dominant. In turn, the highest concentrations of phosphates and potassium occurred on the days when air masses were transported from Vistula Żuławy. All episodes occurred in the spring when agricultural activity related to fertilizing farmland was the highest and the average wind speed was lower than $5 \mathrm{~m} \cdot \mathrm{s}^{-1}$, which indicates local to the regional origin of the analyzed compounds in aerosols.
\end{abstract}

Keywords - Particulate matter, PM10, chemical composition, agriculture influence, southern Baltic coastal zone

Received: November 18, 2021

Accepted: December 10, 2021

\section{INTRODUCTION}

The chemical composition of aerosols is determined by the location of the research area in relation to pollution sources and the prevailing meteorological conditions (Sprovieri et. al., 2011; Gaffke et al., 2016; Witkowska et al., 2016). The rural area is characterized by large areas of arable land from which not only natural soil components can be emitted into the atmosphere but also compounds fertilization (Jadczyszyn, 2015). This can lead to a reduction in air quality in rural areas. Additionally, as a result of transporting pollutants with air masses over long distances, the influence of agriculture on the chemical composition of the atmosphere is also noted in cities (Satsangi et al., 2012). The technology and the market of artificial fertilizers are dynamically developing in order to ensure high fertility of crops. For this reason, it can be expected that the problem of air pollution-related to agriculture will remain current or even increase in intensity in the coming years. In Poland, nearly $3 / 4$ of the cultivation area is covered by cereals. The most common crops are wheat $(22.4 \%)$ as well as rye $(8.5 \%)$, barley $(7.8 \%)$, and oats $(4.6 \%)$. Tuberous plants 
such as sugar beet and potatoes account for around $4.5 \%$ of the cultivated area. The country has a relatively large harvest of cereals, which is due to a large area of sown crops and the fertilization of the fields. The fertilizers used to enrich the soil in plant cultivation usually contain nitrates, ammonia, phosphates, magnesium, calcium, and potassium ions (Tab. 1). The dominant type of fertilizers used in Poland, due to their effectiveness, are granules. Liquid fertilizers are only an alternative and supplement to granulates (AZOTY GROUP). They are usually sprayed over fields.

Table 1. Composition and frequency of fertilizers used for individual crops (AZOTY GROUP)

\begin{tabular}{|c|c|c|}
\hline Composition & Fertilization frequency & Type of plant \\
\hline $\mathrm{Mg}, \mathrm{Ca}, \mathbf{P}, \mathbf{K}$ & $\begin{array}{l}\text { In spring (for pre-sowing cultivation). In autumn, for } \\
\text { plowing }\end{array}$ & $\begin{array}{c}\text { Spring wheat } \\
\text { Barley } \\
\text { White beet } \\
\text { Rye } \\
\text { Potato } \\
\text { Oat } \\
\end{array}$ \\
\hline \multirow{5}{*}{$\mathbf{N}$} & $\begin{array}{c}\text { Before sowing } \\
\text { At the beginning of shooting at the stalk } \\
\text { At the beginning of heading } \\
\text { When shortening the straw }\end{array}$ & Spring wheat \\
\hline & $\begin{array}{l}\text { Before sowing } \\
\text { In the tillering phase }\end{array}$ & $\begin{array}{c}\text { Barley } \\
\text { Oat }\end{array}$ \\
\hline & $\begin{array}{l}\text { Pre-sowing (spring) x } 2 \\
\text { From 4-5 leaf stage to beginning of inter-row cover }\end{array}$ & White beet \\
\hline & $\begin{array}{c}\text { Pre-sowing with fertilizers } \\
\text { Beginning of vegetation } \\
\text { Start shooting at the blade } \\
\text { Or double dosing at the beginning of spring }\end{array}$ & Rye \\
\hline & $\begin{array}{c}\text { Before planting } \\
\text { After emergence until April } \\
\end{array}$ & Potato \\
\hline \multirow{3}{*}{$\begin{array}{c}\mathrm{NH}_{3} \\
\text { (Spraying) }\end{array}$} & $\begin{array}{l}\text { The final phase of tillering } \\
\text { End of shooting phase }\end{array}$ & $\begin{array}{l}\text { Wheat } \\
\text { Barley } \\
\text { Oat }\end{array}$ \\
\hline & $\begin{array}{l}\text { Beginning of vegetation } \\
\text { End of shooting phase }\end{array}$ & Rye \\
\hline & $\begin{array}{l}\text { From the production of side shoots to the flowering phase } \\
\text { (max. } 7 \text { times) }\end{array}$ & Potato \\
\hline Manure & Late fall & Potato \\
\hline
\end{tabular}

Regardless of the type of crop, the soil is first properly prepared before adding fertilizer. Granules are spread in the amount suggested by the producer on the soil previously sprinkled with water (AZOTY GROUP). This operation is additionally performed before rainfall occurs in order to increase the solubility of the fertilizer and the efficiency of its uptake by plants (AZOTY GROUP). If the soil is strongly acidic, powdered carbonate lime is sprinkled on the fields and covered with soil during plowing. Lime fertilization, i.e. liming is usually used on acidic soils $(\mathrm{pH}$ 4.0-5.5) to bring the soil $\mathrm{pH}$ closer to slightly acidic $(\mathrm{pH}$ 5.0-6.0), neutral ( $\mathrm{pH}$ 6.0-7.0) or alkaline $(\mathrm{pH}$ 7.0-8.0). Liming is performed only after harvest, i.e. in late summer or autumn. This process is repeated every 2 years on light soils and every 4 years on heavy soils. If the soils are poor in phosphorus or potassium, fertilizers rich in these elements are added to them. Particularly important is the addition of phosphorus, which determines the proper development of the root system, improves plant rooting, the biological activity of the soil, and also results in better use of other ingredients. Mineral fertilizers rich in potassium and phosphorus are first mixed with the soil and only then spread over the cultivated field. This activity is most often performed in the fall. If fertilizers are additionally enriched with magnesium and calcium, they are introduced into the soil not only in autumn (before plowing), but also in spring (before sowing) in order to increase the plant resistance to pathogens. In turn, to feed the plants and increase the yield, nitrogen fertilizers are used, both in solid (granular) and liquid form. Additionally, leaf spraying is performed (AZOTY GROUP). Fertilization of the soil with nitrogen compounds is carried out in early spring (before sowing) and at the beginning of summer, when the plant begins to grow long (shooting into the stalk). This activity is repeated at the beginning of the heading. In addition to increasing the yield, this leads to an increase in the gluten content in the grains. Some species of crops, such as barley, rye, or potatoes, require $\mathrm{NH}_{3}$ spraying in the final stages of tillering 
or in expansion to length. They prevent fungal diseases and the development of pests (AZOTY GROUP).

The addition of fertilizers plays an undeniably important, positive role in improving the quality of crops and increasing yields. On the other hand, it can lead to air pollution. In the case of granular fertilizers, the release of their components into the atmosphere is associated with wind discharge and re-emission from the surface of the fields. In turn, the compounds included in the liquid fertilizers can be directly adsorbed on atmospheric aerosols during their spraying in the atmosphere. This increases the likelihood of their transport to regions distant from their source of origin. Atmospheric pollution with compounds emitted in agricultural areas does not only occur during field fertilization. It also takes place after each disturbance of the soil structure, e.g. when plowing the soil with a plow, when compact layers of sediment are torn out, which then transferred to the atmosphere in the form of dust and can be transported by the wind. It is plowed 4 times a year, depending on the plant species, in order to aerate the soil. As a result, the soil is less compacted and better hydrated, and the plants can develop the root system more easily. In spring, plowing is carried out under spring plants. In summer, it takes place immediately after harvesting, and in autumn, during pre-sowing cultivation for winter and spring crops (Jabłoński et. al., 1996). The emission of chemical compounds to the atmosphere as a result of the agricultural activity described above can be inhibited by high soil moisture. In addition, Van der Waals forces interact between the water molecules, attracting the molecules and, consequently, increasing their mass and surface area. As a result, even if the grains of sand deposited on water droplets enter the atmosphere, they are so heavy that they may fall onto the soil surface close to the point of their emission (Britannica, 2016).

The fifth producer of cereals in Poland are farmers from the Pomeranian Voivodeship, where over $40 \%$ of the crops are wheat. In addition, barley, rye, and oats are grown in the region, and buckwheat, millet, and maize are also grown in smaller quantities. Apart from cereals, the most numerous group are sugar beets $(699,000$ tons per year) and potatoes (564,000 tons), which are cultivated on an area of over 22,000 hectares (Pomorskie EU). The yields in this region of Poland are increasing every year, which may be due to the increasing use of fertilizers. In the Pomeranian Voivodeship, 114.6 thousand tons of mineral or chemical fertilizers (per pure component) were used only in the 2016/17 marketing year. It was about 12.6 thousand. tons $(12.4 \%)$ more than in previous years (Statistical Office in Gdańsk, 2019).

Taking the above into account the aim of this study was to determine the impact of regional agriculture activity on the chemical composition of aerosols in Gdynia between April and August 2016. At that time, aerosol samples of various sizes were collected only during periods when air masses were flowing from over the agricultural land. The first of them, Vistula Żuławy, is located in the Vistula Delta, southeast of the measuring station. The second area,
Kashubia, is located north-south-west from the measuring station. Both areas are rich in fertile soil, resulting in welldeveloped agriculture. In Żuławy, agricultural areas constitute nearly $94.6 \%$ of the area (Sumiławski et. al., 2013). Mainly grown there are spring wheat, barley, and sugar beet. On the other hand, in Kashubia, which in $42 \%$ is covered by agricultural land, mainly rye and potatoes are grown. Recognition of the chemical composition of aerosols with the influx of air masses from the above-mentioned regions made it possible to determine in which situations over Gdynia air pollution from agricultural sources occurs.

\section{MATERIALS AND METHODS}

\section{Location of the measuring station}

Aerosol samples were collected in Gdynia, on the territory of the Faculty of Oceanography and Geography of the University of Gdańsk ( $\left.54^{\circ} 30^{\prime} \mathrm{N}, 18^{\circ} 32^{\prime} \mathrm{E}\right)$. The building is located in the urbanized part of the city, $560 \mathrm{~m}$ from the shoreline of the Baltic Sea (Gdańsk Bay) (Fig. 1). Gdynia is located in the Pomeranian Voivodeship, in the area of two mesoregions - the Kashubian Coast and the Kashubian Lakeland. Agricultural land in Kashubia constitutes $43 \%$. Of which arable land constitutes $32.8 \%$, orchards - $0.2 \%$, meadows - $6 \%$, and pastures - 4\%. The average area of agricultural land on farms is almost 19 ha, which places the region in third place in the country in this respect. Most of the arable land is located to the north-west and south-west of the measuring station, in Kartuzy district (46.43\% of the entire district). The greatest number of arable lands in the Kartuzy district is in the commune of Przodkowo and Żukowo, as well as Sierakowice, Somonino and Stężyca (Tomaszewska et. al., 2014). Arable land in the Kościerzyna district covers of $33.4 \%$ of the total area, the most in the Kościerzyna commune (9279 ha) and Stara Kiszewa (7559 ha) (Malinowski, 2007). In the structure of land use in the Gdańsk district, the largest share is occupied by agricultural land - over 68\%, including arable land (almost 53\%) (Walkowiak et. al., 2016). The arable lands in the Wejherowo district occupy about $38 \%$ of the total area of the district, including the largest share in the southern part of the district in the following communes: Szemud (65\%), Linie $(51 \%)$, Luzino $(48.6 \%)$ and in the northern part in the commune Choczewo (48\%). The arable lands in the Bytów district cover $33 \%$ of the whole district's area (ZwarowskaMatuga et al., 2003).

The communes with the largest number of agricultural areas lie within 30 to $50 \mathrm{~km}$ from the measuring station in Gdynia. Rye and potatoes are the dominant crops. Rye is sown as much as $36.5 \%$ of the arable land, and potatoes $-14.4 \%$. Wheat accounts for a small percentage (7.5\%), and only $0.5 \%$ is sugar beet. On the other hand, considerable acreage is taken up by forage plants (Olszewski, 1985).

The south-eastern border in Gdańsk is closed by Vistula Żuławy, which lies within the Wielkopolska-Pomeranian agricultural region. Almost the entire area is occupied by agricultural land (94.6\%), and the crops are very 
concentrated. Due to the very fertile soil and large surface water resources, it is one of the largest agricultural complexes in Poland. The structure of soils in Żuławy is dominated by bogs, classified as the most fertile soils. The yields of cereals and oilseeds obtained there are among the highest in the country (Nowiński and Liziński, 2004). Large farms prevail in Vistula Żuławy, the largest of which are those with an area of more than 20 ha. The largest complexes of arable fields are located in the municipalities of Malbork and Nowy Staw (Luterek et. al., 2014). The arable lands in the Malbork County constitute $85 \%$, and in the Nowodworski County $44.97 \%$ of the total geodetic area (Janecka, 2004). The dominant type of agricultural land use is arable land, which covers 35,400 ha out of 41,860 ha of arable land (Bański, 2001).

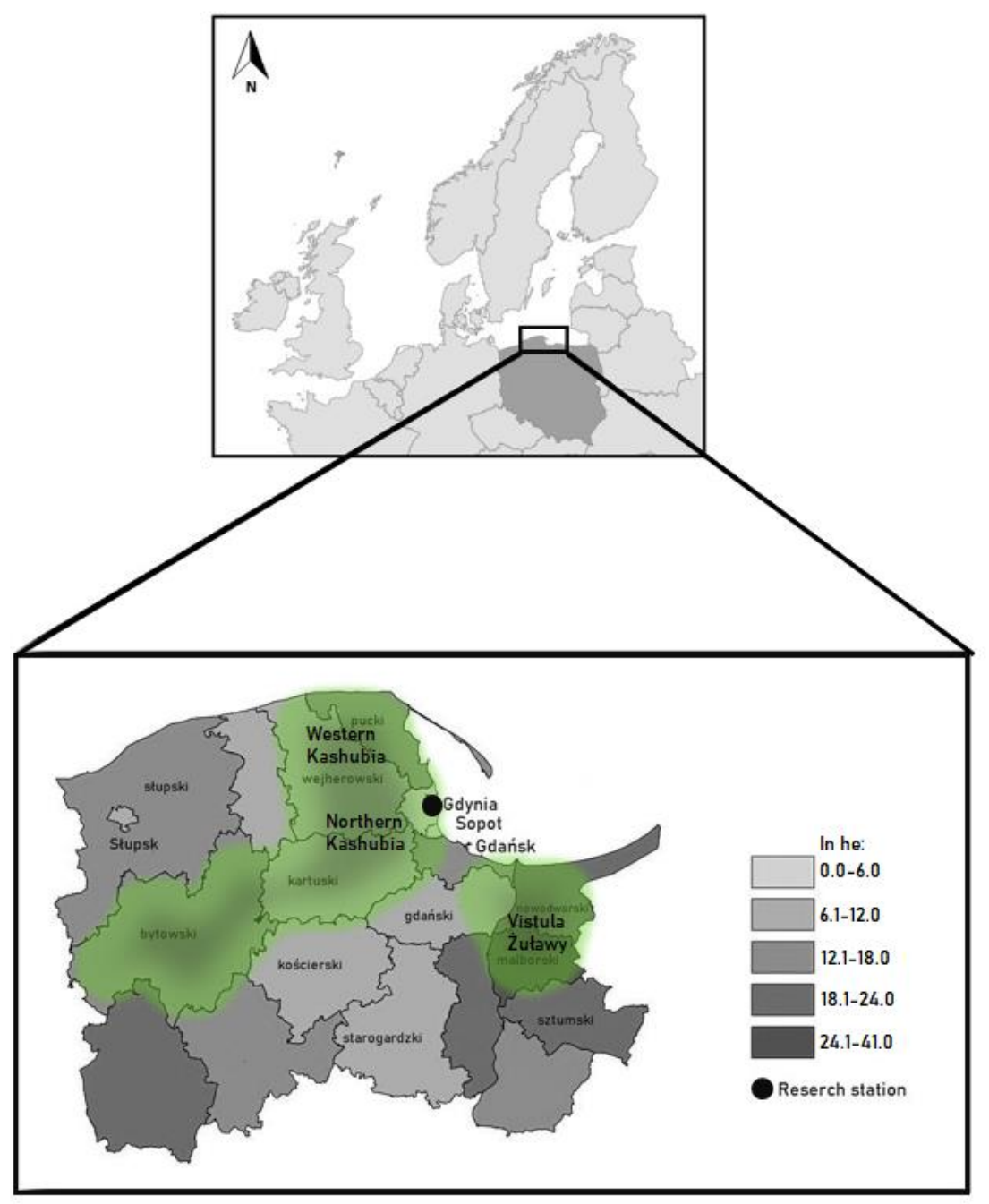

Fig. 1. Location of the measuring station along with the surrounding communication routes

\section{Aerosol sampling}

Aerosol samples were collected in the period from 19/04/2016 to 17/08/2016 (vegetative period). Samples were carried out in a five-hour cycle, outside the rush hours (10:00 am- 3:00 pm). It was aimed at eliminating the source related to the transport as much as possible.

Aerosols were collected using a Tisch Environmental, Inc. high-flow impactor (model: TE-235). It operates at a nominal flow of $1.132 \mathrm{~m}^{3} \cdot \mathrm{min}^{-1}\left(40 \mathrm{scfm} ; 68 \mathrm{~m}^{3} \cdot \mathrm{h}^{-1}\right)$, at a pressure of $760 \mathrm{~mm} \mathrm{Hg}$ and a temperature of $25^{\circ} \mathrm{C}$. Aerosols were collected on TE-QMA Micro Quartz filters, $14.3 \mathrm{~cm} \mathrm{x}$ $13.7 \mathrm{~cm}$ in size (aerosols from $0.49 \mu \mathrm{m}$ to $10 \mu \mathrm{m}$ ). The smallest particles, below $0.49 \mu \mathrm{m}$ were collected on a Whatman 41 filter, which had a size of $20.3 \mathrm{~cm} \times 25.4 \mathrm{~cm}$. Before use, all filters were preheated $\left(580^{\circ} \mathrm{C}, 6 \mathrm{~h}\right)$ and then conditioned in a desiccator for 24 hours (Rh: $45 \% \pm 5 \%$ and $20^{\circ} \mathrm{C} \pm 5^{\circ} \mathrm{C}$ ). All filters were weighed with an accuracy of $10^{-5} \mathrm{~g}$ on a vertical plate of a RADWAG microbalance (AS 110.R2) adjusted to the size of the filters. This operation was performed at least twice. After sampling, the filters were re-conditioned for $48 \mathrm{~h}$ in the desiccator and weighed a minimum of twice again. All activities related to installing, removing, and weighing the filters were carried out in a laminar airflow chamber. The limit of quantification (LoQ) was set at $0.12 \mu \mathrm{g}$ (20 replicates). The uncertainty of the method was $<3.0 \%$ (at a certainty level of $99 \%$ ). 


\section{Anion analysis}

Prior to chromatographic analysis, a fragment of $10.8 \mathrm{~cm}^{2}$ was cut from quartz filters with dimensions of $14.3 \mathrm{~cm} \mathrm{x}$ $13.7 \mathrm{~cm}$, while a fragment of $3.8 \mathrm{~cm}^{2}$ was cut from a filter of $20.3 \mathrm{~cm} \times 25.4 \mathrm{~cm}$. The cut filters were then placed in polyethylene tubes and $12 \mathrm{~cm}^{3}$ of milli-Q water was added. The next step was to sonicate the samples $(20 \mathrm{~min})$ in an ultrasonic bath (Sonic 6D, Sonic 10) in order to bring the ions into solution. The extract obtained in this way was filtered through membrane filters with a pore diameter of $0.2 \mu \mathrm{m}$. The ions $\mathrm{NO}_{3}{ }^{-}, \mathrm{PO}_{4}{ }^{3-}, \mathrm{K}^{+}$and $\mathrm{Ca}^{2+}$ were determined by ion chromatography 881 Compact IC pro (Metrohm) in accordance with Polish Standard PrPN-EN No 10304-1. For all anions and cations, the error of the method was below $5.0 \%$ with a confidence level of $99 \%$.

\section{Variation of meteorological parameters}

Gdynia, where aerosol samples were collected, is located in the temperate climate zone, which is constantly modified by the influence of the vicinity of the Baltic Sea. Such a location determines the less sporogic winters and at the same time not too hot summers. The average annual temperature for the summer period is $14^{\circ} \mathrm{C}$, and for the winter period is $2.3^{\circ} \mathrm{C}$. Average precipitation totals are 590 mm (1971-2000) with maximum values in July (13\%). Winds from the west dominate in Gdynia (1981-2010) (IMGW).

During the research period, the average temperature was equal to $16.17^{\circ} \mathrm{C}$. The highest temperature was recorded on $1^{\text {st }}$ of June $\left(22.39^{\circ} \mathrm{C}\right)$, and the lowest on 22 of April $\left(5.70^{\circ} \mathrm{C}\right)$ (Tab. 2). Relative air humidity ranged from $34.60 \%$ (21.04.2016) to $75.99 \%(30.05 .2016)$ and average was equal to $57.95 \%$. The mean wind speed value was equal to 2.42 $\mathrm{m} \cdot \mathrm{s}^{-1}$. The maximum wind speed was recorded on April 26 $\left(5.7 \mathrm{~m} \cdot \mathrm{s}^{-1}\right)$. The lowest wind speed was recorded on June 27 and it was equal to $0.3 \mathrm{~m} \cdot \mathrm{s}^{1}$ (Tab. 2). During the whole period, the north-east direction (41\%) was dominant. Directions from east and west counted for $20 \%$ each (Tab. 2).

\section{RESULTS AND DISCUSSION}

During the entire measurement period, the average PM10 concentration in the five-hour measurement cycle was 47.27 $\mu \mathrm{g} \cdot \mathrm{m}^{-3}$ (Tab. 2). The lowest mean value of PM10 concentration $\left(4.10 \mu \mathrm{g} \cdot \mathrm{m}^{-3}\right)$ was obtained in the range of aerosol sizes from 1.5 to $3.0 \mu \mathrm{m}$ in diameter. The maximum mean concentration of PM10 was $18.63 \mu \mathrm{g} \cdot \mathrm{m}^{-3}$ and it was obtained in the range of aerosols with the largest diameter (7.2-10 $\mu \mathrm{m})$. The minimum concentration of PM10 was $26.00 \mu \mathrm{g} \cdot \mathrm{m}^{-3}$ and it was recorded on May 12.05.2016 while the maximum concentration was $65.89 \mu \mathrm{g} \cdot \mathrm{m}^{-3}$ and it was obtained on April 19.04.2016.

In the five-hour cycle of tests carried out in Gdynia in the period from $19 / 04 / 2016$ to $17 / 08 / 2016$, calcium ions dominated among the analyzed PM10 ionic components (91.2\%). The median $\mathrm{Ca}^{2+}$ concentration was also the highest and amounted to $2.81 \mu \mathrm{g} \cdot \mathrm{m}^{-3}$ (Fig. 2). The remaining ions constituted on average: $\mathrm{NO}_{3}{ }^{-}-3,5 \%, \mathrm{PO}_{4}{ }^{3-}-4,8 \%$, a K${ }^{+}-$ $0,5 \%$ of the PM10 mass. During the research period, the median $\mathrm{NO}_{3}{ }^{-}$concentration was $0.06 \mu \mathrm{g} \cdot \mathrm{m}^{-3}$. The extreme values of the concentration of these ions in PM10 have been recorded: $1.10 \mu \mathrm{g} \cdot \mathrm{m}^{-3}(10.05), 1.09 \mu \mathrm{g} \cdot \mathrm{m}^{-3}(27.04), 1.06$ $\mu \mathrm{g} \cdot \mathrm{m}^{-3}$ (26.04), $1.03 \mu \mathrm{g} \cdot \mathrm{m}^{-3}(12.05)$ and $0.89 \mu \mathrm{g} \cdot \mathrm{m}^{-3}(19.04)$.

Table 2. Statistical characteristics of meteorological data during the research conducted in Gdynia in 2015

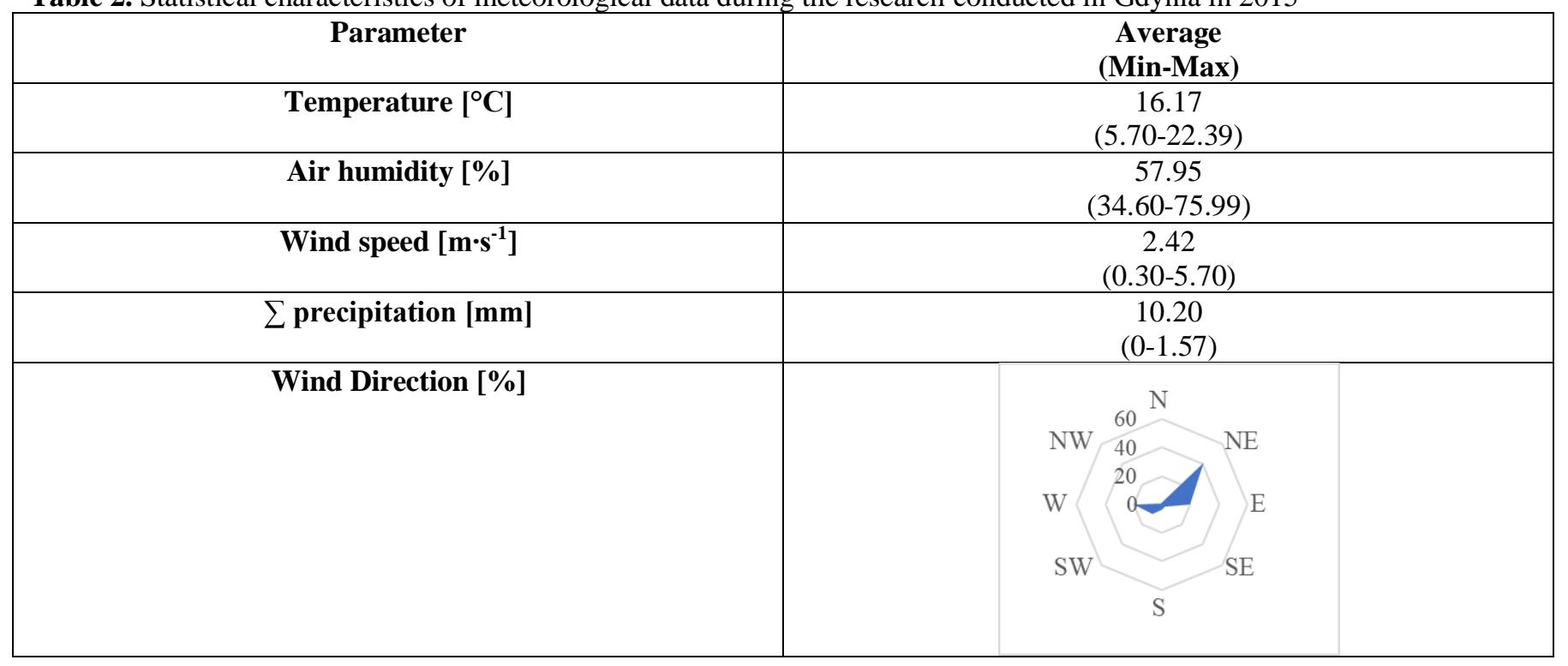


Table 3. Average values and concentration range (min-max) of PMx and selected ionic components depending on the size of aerosols collected in Gdynia in the period from April to August 2016.

\begin{tabular}{|c|c|c|c|c|c|c|}
\hline \multirow{2}{*}{$\begin{array}{c}\text { Parameter } \\
{\left[\mu \mathrm{g} \cdot \mathrm{m}^{-3}\right]}\end{array}$} & \multicolumn{6}{|c|}{ Aerosol size $[\mu \mathrm{m}]$} \\
\hline & $<0.49$ & 0.49-0.95 & 0.95-1.5 & $1.5-3.0$ & 3.0-7.2 & $7.2-10$ \\
\hline PMx & $\begin{array}{c}9.83 \\
(5.95-13.16)\end{array}$ & $\begin{array}{c}4.14 \\
(0.42-6.93)\end{array}$ & $\begin{array}{c}4.19 \\
(1.44-7.77)\end{array}$ & $\begin{array}{c}4.10 \\
(1.79-6.52)\end{array}$ & $\begin{array}{c}4.95 \\
(2.61-7.53)\end{array}$ & $\begin{array}{c}18.63 \\
(6.18-39.07)\end{array}$ \\
\hline $\mathrm{NO}_{3}^{-}$ & $\begin{array}{c}0.25 \\
(0.02-0.87)\end{array}$ & $\begin{array}{c}0.05 \\
(0.01-0.10)\end{array}$ & $\begin{array}{c}0.06 \\
(0.01-0.17)\end{array}$ & $\begin{array}{c}0.04 \\
(\mathrm{LoQ}-0.11)\end{array}$ & $\begin{array}{c}0.08 \\
(0.01-0.30)\end{array}$ & $\begin{array}{c}0.19 \\
(0.02-0.68)\end{array}$ \\
\hline $\mathrm{PO}_{4}{ }^{3-}$ & $\begin{array}{c}0.08 \\
(0.02-0.19)\end{array}$ & $\begin{array}{c}0.13 \\
(0.02-0.22)\end{array}$ & $\begin{array}{c}0.19 \\
(0.14-0.28)\end{array}$ & $\begin{array}{c}0.19 \\
(0.07-0.33)\end{array}$ & $\begin{array}{c}0.17 \\
(0.04-0.31)\end{array}$ & $\begin{array}{c}0.17 \\
(0.05-0.30)\end{array}$ \\
\hline $\mathbf{K}^{+}$ & $\begin{array}{c}0.04 \\
(0.01-0.09)\end{array}$ & $\begin{array}{c}0.01 \\
(\mathrm{LoQ}-0.03)\end{array}$ & $\begin{array}{c}0.01 \\
(\mathrm{LoQ}-0.05)\end{array}$ & $\begin{array}{c}0.02 \\
(\mathrm{LoQ}-0.05)\end{array}$ & $\begin{array}{c}0.01 \\
\text { (LoQ-0.03) }\end{array}$ & $\begin{array}{c}0.01 \\
(\mathrm{LoQ}-0.03)\end{array}$ \\
\hline $\mathrm{Ca}^{2+}$ & $\begin{array}{c}5.64 \\
(2.17-8.21) \\
\end{array}$ & $\begin{array}{c}2.23 \\
(0.36-5.46)\end{array}$ & $\begin{array}{c}2.32 \\
(0.12-5.66) \\
\end{array}$ & $\begin{array}{c}2.08 \\
(0.12-3.93) \\
\end{array}$ & $\begin{array}{c}2.89 \\
(0.37-5.26) \\
\end{array}$ & $\begin{array}{c}2.44 \\
(0.19-5.25)\end{array}$ \\
\hline
\end{tabular}

The median concentration of 0.17 was $\mu \mathrm{g} \cdot \mathrm{m}^{-3}$. There were no extreme values for phosphate ions. The median concentration of potassium ions $\left(\mathrm{K}^{+}\right)$was $0.1 \mu \mathrm{g} \cdot \mathrm{m}^{-3}$. The extreme values for $\mathrm{K}^{+}$reached $0.18 \mu \mathrm{g} \cdot \mathrm{m}^{-3}$ (19.04), 0.16 $\mu \mathrm{g} \cdot \mathrm{m}^{-3}$ (26.04 and 17.08) and $0.18 \mu \mathrm{g} \cdot \mathrm{m}^{-3}$ (19.04).

The percentages of $\mathrm{NO}_{3}{ }^{-}, \mathrm{K}^{+}, \mathrm{Ca}^{2+}$, as well as their median concentrations, were the highest in aerosols with a diameter below $0.45 \mu \mathrm{m}$ (Tab. 3). Nitrate ions accounted for $37.3 \%$, potassium ions $40.0 \%$, and calcium ions $32.6 \%$ by weight of the aerosols in this particle size range. The highest percentage of $\mathrm{PO}_{4}{ }^{3-}$ was recorded in aerosols with a diameter ranging from 0.95 to $1.5 \mu \mathrm{m}(20.4 \%)$ and from 1.5 to $3 \mu \mathrm{m}(20.5 \%)$. However, the mean concentration of phosphate ions was very similar for particles larger than $0,95 \mu \mathrm{m}$ and ranged from 0.17 to $0.19 \mu \mathrm{g} \cdot \mathrm{m}^{-3}$. Particles smaller than $0.95 \mu \mathrm{m}$ were characterized by twice lower mean concentration values, ranging from $0.08 \mu \mathrm{g} \cdot \mathrm{m}^{-3}(<0.49$ $\mu \mathrm{m}$ in diameter) to $0.013 \mu \mathrm{g} \cdot \mathrm{m}^{-3} \quad(0.49-0.95 \mu \mathrm{m})$. All analyzed ions were characterized by higher concentrations in the aerosols in the range up to $3 \mathrm{~mm}$ than above $3 \mathrm{~mm}$ in diameter (Fig. 3). The median concentration of potassium ions and calcium ions was twice as high in the smaller fraction of the aerosols than in the larger one (Fig. $3 \mathrm{~b}$ i $3 \mathrm{~d})$. During the entire research period, episodes of high concentrations of the analyzed ionic PM10 components were selected, which could be related to agricultural activity in the neighboring areas (Tab. 4).

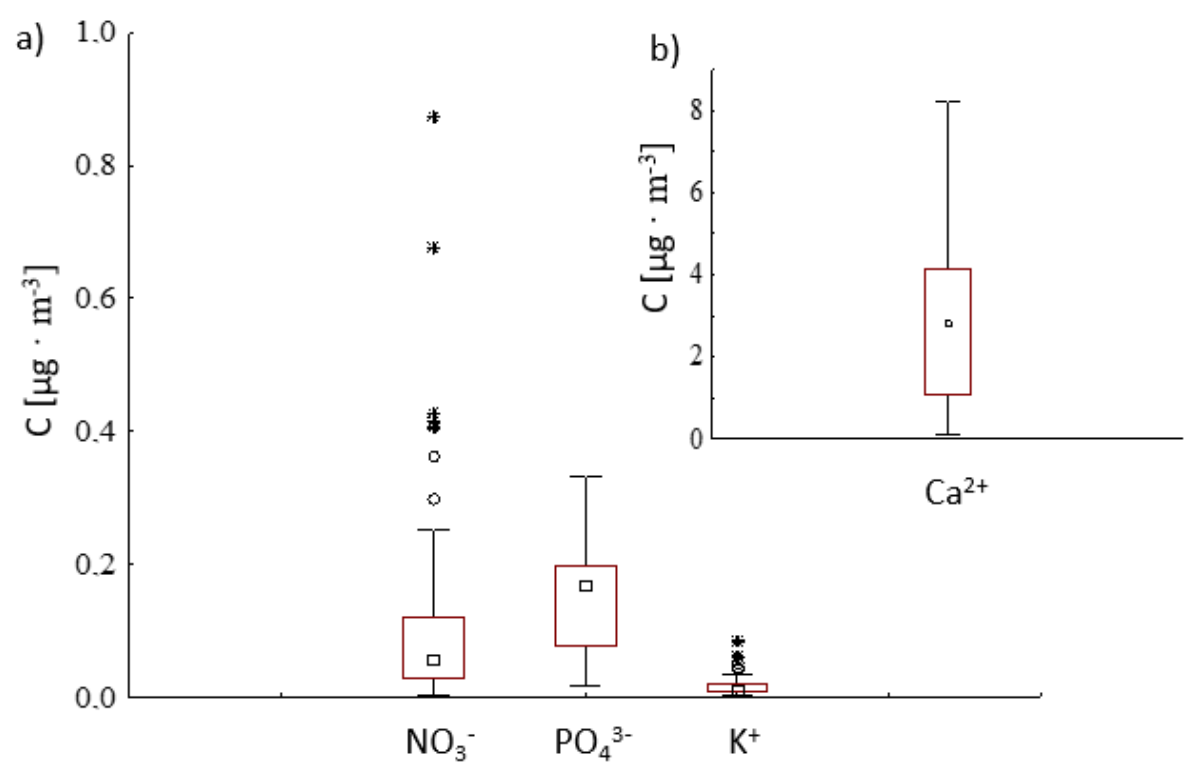

Fig.2 Range of analyzed ions concentration in aerosols collected in air over Gdynia between April and August 2016 

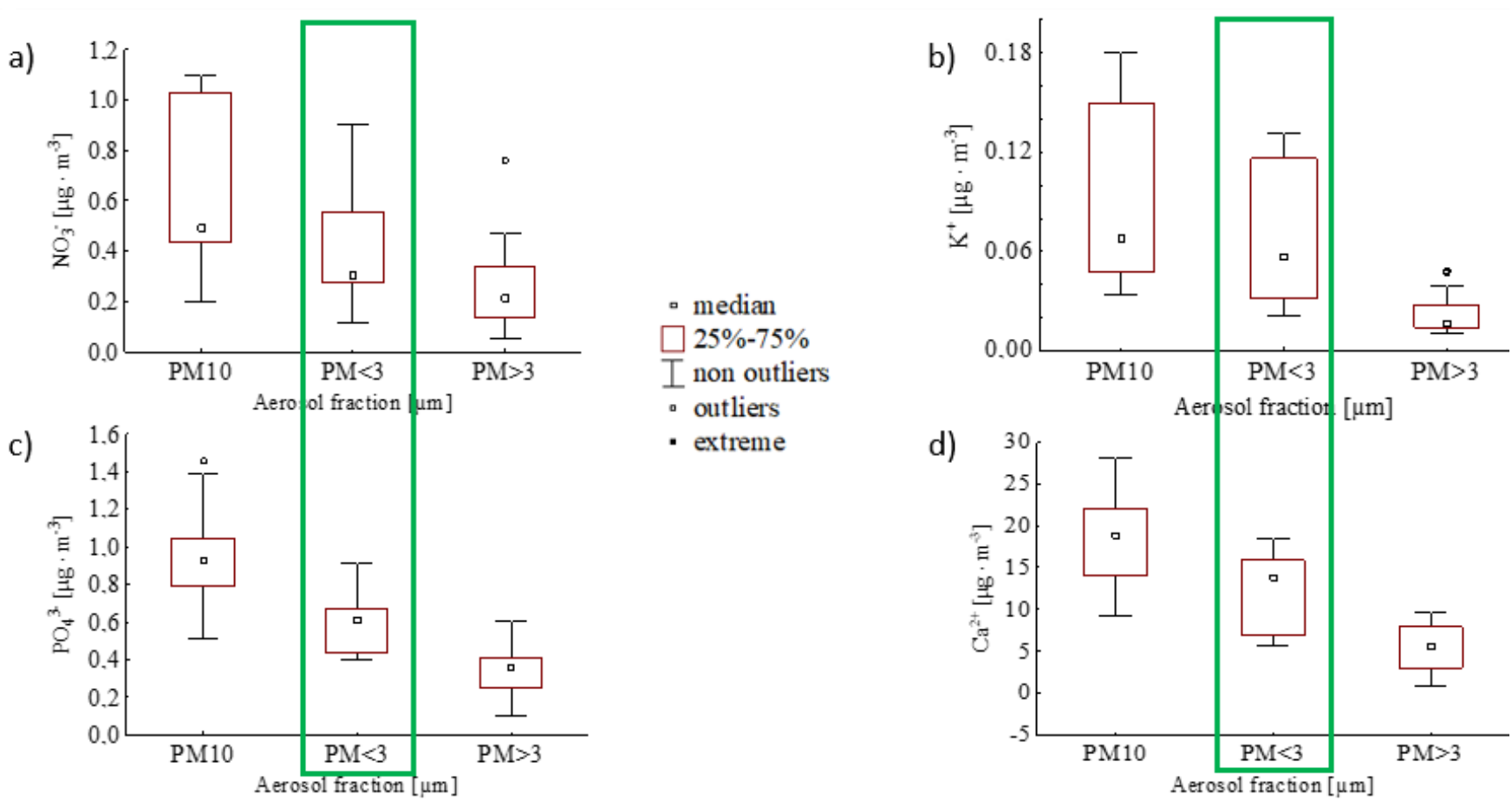

Fig. 3 Variability of $\mathrm{NO}_{3}{ }^{-}, \mathrm{PO}_{4}{ }^{3+}, \mathrm{K}^{+}$and $\mathrm{Ca}^{2+}\left[\mu \mathrm{g} \cdot \mathrm{m}^{-3}\right.$ ] concentration in aerosols collected in the air over Gdynia between April and August 2016.

The air masses from over the Western Kashubia applied pollutants on April 19 and 21, June 27, and August 16 and 17,2016 . At that time, wind velocities ranged from 1.1 to $3.3 \mathrm{~m} / \mathrm{s}$ what is characteristic for local to the regional origin of air pollution (Lewandowska et. al., 2013). In turn, the air masses from the Żuławy Wiślane region, which could transport pollutants of agricultural origin, occurred on April 26 and 27, May 30 and 30, and June 1, 2016. In this case, winds with a force indicating the transfer of pollutants on a regional scale (from 2.5 to $4.2 \mathrm{~m} / \mathrm{s}$ ) prevailed (Tab. 4 ).

Table 4. Episodes of potential agriculture source of origin of PM10 and its chemical components measured in Gdynia between 19/04/2016 and 17/08/2016.

\begin{tabular}{|c|c|c|c|}
\hline Date & Dominating air masses & $\begin{array}{c}\text { Average } \\
\text { wind speed } \\
{[\mathrm{m} / \mathrm{s}]}\end{array}$ & Region of origin \\
\hline 19.04 & & 3.30 & Western Kashubia \\
\hline 21.04 & & 2.70 & Western Kashubia \\
\hline
\end{tabular}




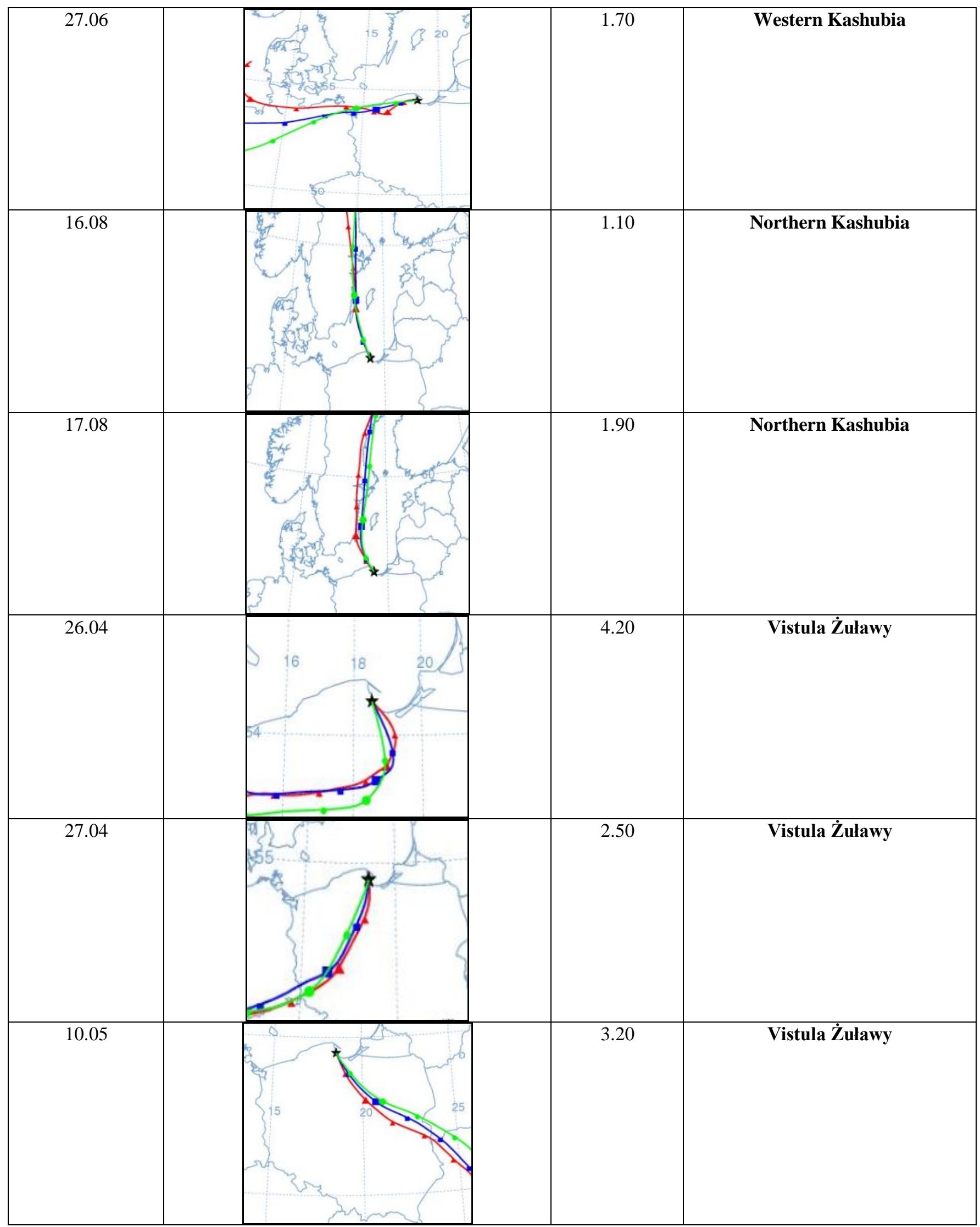




\begin{tabular}{|l|l|l|l|l|}
\hline 30.05 & 2.60 & Vistula Żulawy \\
\hline 01.06 & Vistula Żulawy & \\
\hline
\end{tabular}

It was found that the highest concentration of nitrate ions occurred on April $19\left(0.89 \mu \mathrm{g} \cdot \mathrm{m}^{-3}\right)$, during advection from the Western Kashubia and in the period from April 26 to May 10 (od 1.06 do $1.10 \mu \mathrm{g} \cdot \mathrm{m}^{-3}$ ), when air masses from above Vistula Żuławy (Fig. 4a). Higher concentrations of these ions in the atmosphere could be a consequence of fertilizing the soil with nitrogen compounds, which is usually carried out in early spring (before sowing) when the plant begins to grow long (shooting into the stem) (AZOTY GROUP). On May 10, there was a rainfall that effectively cleaned the atmosphere of nitrate ions, and their concentration on May 11 decreased to $0.31 \mu \mathrm{g} \cdot \mathrm{m}^{-3}$. The decrease in $\mathrm{NO}_{3}{ }^{-}$concentration was also noted earlier, after the rain episode on April 19 (from 0.89 to $0.63 \mu \mathrm{g} \cdot \mathrm{m}^{-3}$ ). The increase in the concentration of nitrate ions in aerosols collected over Gdynia took place yet only on May 12 (1.03 $\mu \mathrm{g} \cdot \mathrm{m}^{-3}$ ) and was rather a consequence of the application of local pollutants, considering that the average wind force did not exceed $<0.5 \mathrm{~m} / \mathrm{s}$. Taking into account the location of the station in the city center, the high concentration of nitrates could be related to the emission of exhaust fumes from road transport. Nitrates dominated in the small fraction of aerosols, below $3 \mu \mathrm{m}$ in diameter (Fig. 4a). Low wind speed, in turn, contributed to poor dispersion of pollutants on that day (Gariazzo et. al., 2007).

Phosphate ions were characterized by the highest concentrations also on April $19\left(1.46 \mu \mathrm{g} \cdot \mathrm{m}^{-3}\right)$, when air masses were flowing from over the Western Kashubia (Fig. 4b). Their concentration was high in aerosols also on April 26, May 11, and August 17 (0.99, 1.10, and $1.89 \mu \mathrm{g} \cdot \mathrm{m}^{-3}$, respectively). In the first two days, the advection from the Vistula Żuławy was dominant, and in the second from northern Kashubia. In both cases, the wind speeds indicated a regional source of pollution $(4.2$ and $3.9 \mathrm{~m} / \mathrm{s}$ and $3.5 \mathrm{~m} / \mathrm{s}$, respectively, in advection from Vistula Żuławy and northern Kashubia). In general, a slight increase in the concentration of phosphate in aerosols was observed from the spring period to the end of the measurements, which took place in the summer (August 17). Throughout the measurement period, phosphates dominated in small particles with a diameter not exceeding $3 \mathrm{~mm}$. Phosphates are introduced into the soil with fertilizers in the greatest amounts in the fall before plowing, to improve the rooting of plants, although often their addition is also necessary in the spring before sowing to increase the resistance of plants to pathogens (Karamesouti and Gasparatos, 2017).

The concentration of calcium ions was generally characterized by an order of magnitude higher than the remaining analyzed aerosol components (Tab. 2). It gradually increased from April $19\left(9.17 \mu \mathrm{g} \cdot \mathrm{m}^{-3}\right)$ to May 10 , when it reached the highest value of $28.14 \mu \mathrm{g} \cdot \mathrm{m}^{-3}$ (Fig. 4c). On that day, as well as on the previous several measurement days, air masses of a regional nature were transported from the Vistula Żuławy region. They were responsible for introducing calcium, especially with small size aerosols, not exceeding $3 \mu \mathrm{m}$ in diameter (Tab. 3). On May 11, rainfall took place which effectively cleared the atmosphere of calcium-rich aerosols on May $12\left(14.55 \mu \mathrm{g} \cdot \mathrm{m}^{-3}\right)$. The concentration of this component increased yet only on May 30 , when on average it reached the value of $26.14 \mu \mathrm{g} \cdot \mathrm{m}^{-3}$ and was close to the concentration recorded during the first episode of high concentrations on May 10. As then, over Gdynia air masses from the Vistula Żuławy region were transported (Tab. 3). The observations made allowed us to conclude that this region (compared to Kashubia) played a key role in shaping high concentrations of calcium ions in aerosols. The lowest recorded concentrations of calcium in aerosols occurred on April 21 during advection from the western Kashubia and on August 17, when the advection from the northern Kashubia dominated $\left(9.48\right.$ and $9.19 \mu \mathrm{g} \cdot \mathrm{m}^{-}$ ${ }^{3}$, respectively Perhaps the high proportion of calcium in the aerosols flowing from this direction is related to the type of soil present in this way. Mady dominates in Zuławy Wiślane. If they were of marine origin (the so-called marches), they could be saturated with salt and calcium compounds (Brożek and Zwydak, 2003). 
The concentration of potassium ions in aerosols collected over Gdynia in the period from April to August 2016 was the most interesting (Fig. 4d). The concentration of this component was the lowest among all analyzed ions (Tab. 2). An increase in the concentration of this aerosol component was recorded only in the period from 19 to 27 April (od 0.19 do $\left.0.12 \mu \mathrm{g} \cdot \mathrm{m}^{-3}\right)$ and 17 August $\left(0.17 \mu \mathrm{g} \cdot \mathrm{m}^{-3}\right)$, although it was insignificant. It concerned potassium ions in small aerosols, up to $3 \mu \mathrm{m}$ in diameter (Fig. 4d). Polish soils are low in potassium. Up to $40 \%$ of them show its deficiency. This is the second, after acidic, factor that can limit the amount and quality of crops. Despite this, phosphate fertilizers are added to the soil only in the fall. This could be of importance for the low phosphate concentration. In addition, potassium, apart from nitrogen, is taken up by plants in the greatest amounts. With high yields, even over $300 \mathrm{~kg} / \mathrm{ha} \mathrm{K}_{2} \mathrm{O}$ can be collected. On average, this value is in the range of $120-180 \mathrm{~kg} / \mathrm{h}$. During the period of intensive growth, some plant species, especially those producing only vegetative parts (e.g. root crops), consume even several $\mathrm{kg} / \mathrm{ha}$ of potassium $\left(\mathrm{K}_{2} \mathrm{O}\right)$ daily (Szewczuk et. al., 2008). Our research was carried out in the period from April to August, which probably led to their low concentrations in atmospheric aerosols during the period of the highest demand in soil.

\section{Conclusions}

Aerosol sampling carried out in Gdynia in the vegetative period from 19/04/2016 to 17/08/2016 was concentrated on agriculture activity role in shaping high ion concentration in PM10. The obtained results allowed to establish that:
1. The highest mean concentrations of $\mathrm{NO}_{3}{ }^{-}, \mathrm{K}^{+}$ and $\mathrm{Ca}^{2+}$ occurred in aerosols below $0.45 \mu \mathrm{m}$ in diameter $\left(0.26 \mu \mathrm{g} \cdot \mathrm{m}^{-3}, 0.04 \mu \mathrm{g} \cdot \mathrm{m}^{-3}\right.$ and $5.85 \mu \mathrm{g} \cdot \mathrm{m}^{-3}$, respectively). Phosphates showed a high average concentration (0.19 $\left.\mu \mathrm{g} \cdot \mathrm{m}^{-3}\right)$ in aerosols with a diameter from 1.5 to $3.0 \mu \mathrm{m}$.

2 . The highest concentrations of nitrate ions in aerosols over Gdynia occurred both during advection from the Western Kashubia and Vistula Żuławy in early spring, before sowing when the plants begin to grow long, which requires nitrogen fertilization.

3. The concentration of phosphates in aerosols over Gdynia increased slightly from spring to summer 2016, also in situations when air masses were flowing from the West Kashubia and Vistula Żuławy regions. This could be a consequence of introducing these ions into the soil with fertilizers in order to increase the resistance of plants to pathogens.

4. Advection from the area of Vistula Żuławy, where seaorigin sludge rich not only in salt but also in calcium compounds, played a key role in shaping high concentrations of calcium ions in aerosols over Gdynia in the discussed research period.

5. Potassium ion concentrations were the lowest among all the analyzed compounds in aerosols collected from April to August 2016 in the atmosphere over Gdynia. It could have been a consequence of the effective uptake of these compounds by plants from the soil.

6. Meteorological factors significantly determined the concentration of the analyzed aerosol components. Rainfall was effective in removing ions from the atmosphere, leading to a decrease in their concentration in aerosols. In turn, the wind speed maintained at the level of $2.4 \mathrm{~m} / \mathrm{s}$ was responsible for the deposition of regional pollutants.
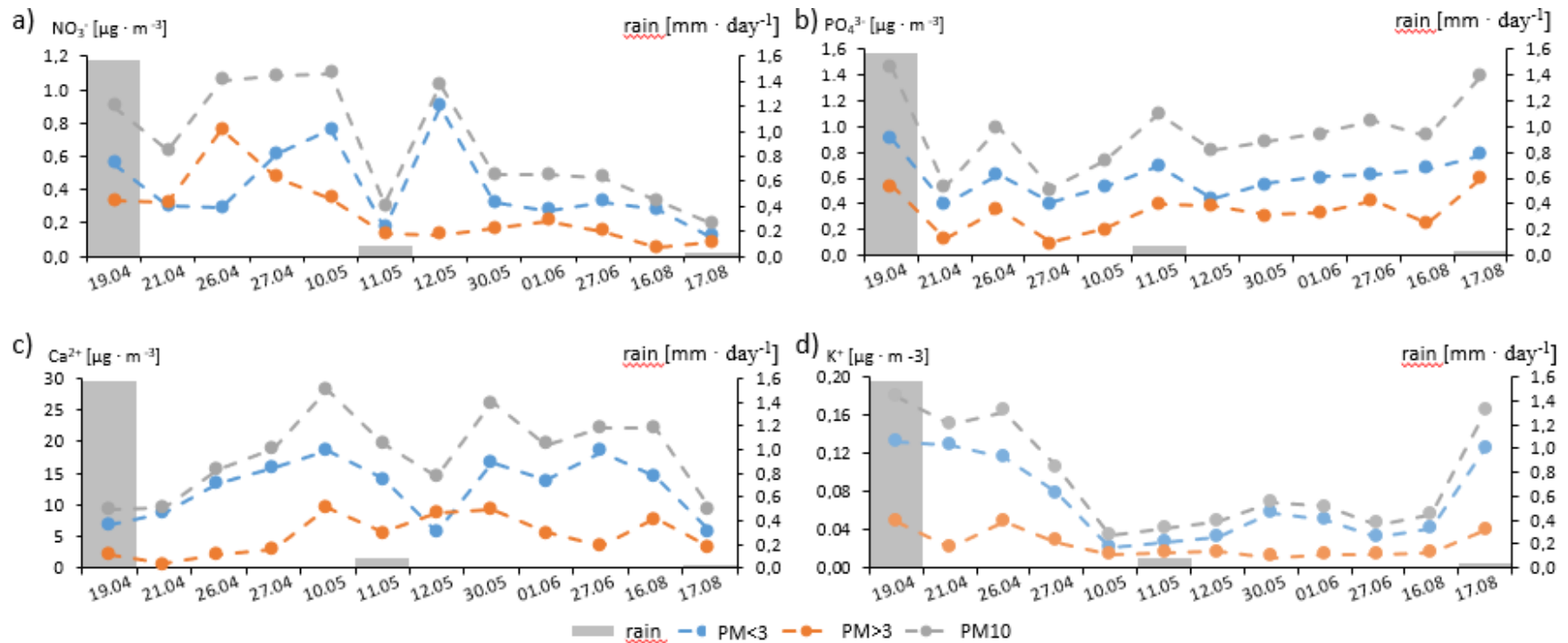

Fig. 4 Variability of the concentration of ionic components of aerosols measured in Gdynia between 19/04/2016 and $17 / 08 / 2016$ 


\section{REFERENCES}

Bański J., 2001, The condition and prospects of agriculture in problem areas in Poland, Geographical Documentation, 22, PAN IGiPZ, Warszawa, in polish

Britannica, The Editors of Encyclopaedia. "Van der Waals forces". Encyclopedia Britannica, 16 Mar. 2016 https://www.britannica.com/science/van-der-Waals-forces (Accessed 5 November 2021)

Brożek S., Zwydek M. (2003) Classification of forest soils in Poland. 2000. Collective work. CILP., Atlas of forest soils of Poland, in polish

Mayor of the City of Bytów (2004) Environmental Protection Program for the urban-rural commune of Bytów https://docplayer.pl/19085846-Program-ochronysrodowiska-dla-gminy-bytow.html (Accessed 5 November 2021)

Gaffke J., Lewandowska A., Bartkowski K. (2015) Polycyclic Aromatic Hydrocarbons (PAHs) in the atmosphere of the Baltic Sea Region, Ecocycles 1(2) 51-55 ISSN 2416-2140. doi: 10.19040/ecocycles.v1i2.44

Gariazzo C., Silibello C., Finardi S., Radice P., Piersanti A., Calori G., Cecinatoc A., Perrinoc C. , Nussio F., Cagnoli M., Pelliccion A., Gobbie G.P., Di Filippo P. (2007) A gas/aerosol air pollutants study over the urban area of Rome using a comprehensive chemical transport model. Atmos. Environ. 41 (34), 7286-7303.)

DOI: $10.1016 /$ j.atmosenv.2007.05.018

\section{AZOTY GROUP}

https://nawozy.eu/wiedza/poradnik-nawozenia/uzytkizielone.html

(Accessed 5 November 2021)

Jabłoński B., Świętochowski B., Krężel R., Radomska M. Soil cultivation technology. In: General cultivation of soil and plants (collective work) (1996) State Agricultural and Forest Publishing House, Warsaw, 4, 130-152, ISBN 83-0901548-8, in polish

Jadczyszyn T. (2015) Good practices in agricultural areas particularly exposed to nitrates (OSN) from agricultural origin, "European Agricultural Fund for Rural Development: Europe investing in rural areas", in polish http://iung.pl/dpr/Mat_szkoleniowe/publ_azotany.pdf

Janecka K., Bujakowska K. (2004) Environmental Protection Program for the Nowodworski District, in polish. https://www.bip.nowodworski.pl/plik,465,plik-dopobrania.pdf (Accessed 5 November 2021)

Karamesouti M., Gasparatos D. (2017) Sustainable management of soil phosphorus in a changing world. W: A. Rakshit et al. (eds.), Adaptive Soil Management: From Theory to Practices, 189-214
DOI: $10.1007 / 978-981-10-3638-5 \_9$

Lewandowska A., Falkowska L. (2013) High concentration episodes of PM10 in the air over the urbanized coastal zone of the Baltic Sea (Gdynia-Poland). Atmos Res 120121:55-67

DOI: $\underline{10.1016 / \text { j.atmosres.2012.08.002 }}$

Luterek B., Altenhof E., Popławska J., Zakrzewska B., Szymkowiak P. (2014) Department of Environment and Agriculture of the Poviat Starosty in Malbork, District Environmental Protection Program for the Poviat of Malbork for the years 2015-2018 with the perspective for the years 2019-2020, in polish

Malinowski A. (2007) Environmental Protection Program for the Kościerzyna District for the years 2008-2011, taking into account the perspective for the years 2012-2015, in polish

https://www.powiatkoscierski.pl/asp/pliki/PDF/pos.pdf (Accessed 5 November 2021)

Meteo IMGW
www.imgw.pl (Accessed 5 November 2021)

Nowicki J., Liziński T. (2004) Natural and technical conditions for the development of agriculture in the Vistula Żuławy Region, Water-Environment-Rutal Areas, 4, 2a(11), 51-62, in polish

Olszewski T. (1985) Polish Agriculture Geography. Warsaw: State Economic Publishing House, 95. ISBN 83-208-04248, in polish

Pomorskie.EU, Portal of the Self-government of the Pomeranian Voivodeship,https://pomorskie.eu/rolnictwo-napomorzu/ (Accessed 5 November 2021)

Satsangi A, Pachauri T, Singla V, Lakhani A, Kumari M (2012) Organic and elemental carbon aerosols at a suburban site. Atmos Res 113:13-21

Sprovieri F., Bencardino M., Cofone F. \& N. Pirrone (2011) Chemical Composition of Aerosol Size Fractions at a Coastal Site in Southwestern Italy: Seasonal Variability and Transport Influence, Journal of the Air \& Waste Management Association, 61:9, 941-951,

DOI: $\underline{10.1080 / 10473289.2011 .599267}$

Statistical Office in Gdańsk (2019) Agriculture in Pomorskie Voivodship in 2018

file:///C:/Users/ACER/Downloads/rolnictwo_w_woj_pomor skim_w_2018_3\%20(10).pdf (Accessed 5 November 2021)

Sumiławski K., Szymańska E., Wesołowska J., Kozdemba K. (2013) Agricultural and Fisheries Development Prospects in the Vistula Delta, Studia KPZK, 146, ISSN 0079-3507, in polish https://journals.pan.pl/Content/96852/mainfile.pdf (Accessed 5 November 2021) 
Szewczuk, A., Komosa, A., \& Gudarowska, E. (2008) Effect of soil potassium levels and different potassium fertilizer forms on yield and storability of Golden delicious apples. Acta Scientiarum Polonorum Hortorum Cultus, 7(2), 53-59

Tomaszewska J., M., Turowska S., Walkowiak J. (2014) Environmental Protection Program for the Kartuzy County for 2015-2018 with a perspective for 2019-2022, in polish http://www.lgrkaszuby.pl/edc_media/Lite/Item-

0249/TinyFiles/Pos-pow.kartuski-01.08.pdf (Accessed 5 November 2021)

Walkowiak J., Karkowski A., Pająk W. (2016) Update of the Environmental Protection Program for the Gdańsk District for 2016-2019 with an perspective until 2023, in polish http://powiat-

gdanski.biuletyn.net/fls/bip_pliki/2016_10/BIPF53DF58E26 FCEZ/2016_10_03_POS_pow_gdanski_25.08.16.pdf

(Accessed 5 November 2021)

Witkowska A., A.U. Lewandowska, D. Saniewska, L.M. Falkowska, 2016. Effect of agriculture and vegetation on carbonaceous aerosol concentrations (PM2.5 and PM10) in Puszcza Borecka National Nature Reserve (Poland). Air Quality, Atmosphere and Health, Vol. 9(7), 761-773.

Zwarowska- Matuga W., Chrząstek J., Kobiela K., Moczulski M., Wilk M., Zarzycki J. (2003) Environmental Protection Program for the District of Wejherowo for 20042011, in polish

https://bip.powiatwejherowski.pl/uploads/files/migration/20 11/11/27/18958.pdf (Accessed 5 November 2021)

(C) 2021 by the author(s). This article is an open-access article distributed under the terms and conditions of the Creative Commons Attribution (CC BY) licence (http://creativecommons.org/licenses/by/4.0 